\title{
Illness and Self-help in Late Eighteenth- Century Rural Switzerland The Strategies of Ulrich Bräker (1735-1798)
}

\author{
Susanne Hoffmann
}

I $\mathrm{n}$ a representative survey on health care in Germany just 35 percent of the interviewees over 16 years recently maintained that they immediately consulted a doctor when they felt ill - in other words: 65 percent trust in self-help. ${ }^{1}$ In comparison, self-help constituted an even more important strategy in early modern times to restore one's health and cope with hardships caused by illness (or other incidents during the course of life). ${ }^{2}$ We know from Lucinda McCray Beier's work on Ralph Josselin (1616-1683), the then Vicar of Earls Colne in Essex, that he and people close to him, as he reported in his diary, consulted professional healers only in 2.8 percent of all cases of illness. ${ }^{3}$ A similar pattern of health behavior can be seen in Ulrich Bräker's writings.

The Swiss Ulrich Bräker (1735-1798), married to Salome Ambühl (1735-1822) with whom he had seven children, spent most of his life in the rural Toggenburg area (located in the present-day canton St. Gallus). ${ }^{4}$ The family owned a house in a

1 Psychonomics AG, Health Care Monitoring 2004, quoted in Heike Krüger-Brand, "Vom Arzt zum Apotheker", Deutsches Ärzteblatt, Praxis 101 (2004), 4, p. 4.

2 Cf. Robert Jütte, Poverty and Deviance in Early Modern Europe (Cambridge et al., 1994), p. 83. In what follows the term "self-help", as opposed to outside or formal help, will be used for "the ability of individuals to endure a period of poverty or distress beyond the short-term logic of the market economy without asking for assistance", Martin Dinges, "Self-Help and Reciprocity in Parish Assistance: Bordeaux in the Sixteenth and Seventeenth Centuries", in Peregrine Horden and Richard Smith, eds., The Locus of Care: Families, Communities, Institutions, and the Provision of Welfare since Antiquity (London, 1998), p. 113.

3 Lucinda McCray Beier, Sufferers \& Healers. The Experience of Illness in SeventeenthCentury England (London/New York, 1987), p. 198 et seq.

4 Cf. Holger Böning, Ulrich Bräker: Der Arme Mann aus dem Toggenburg - Eine Biographie, überarbeitete und ergänzte Neuauflage (Zürich, 1998) for Ulrich Bräker's biography. If not otherwise indicated biographical information (birth and death) of persons in Bräker's surrounding quoted according to Christian Holliger et al., Chronik Ulrich Bräker: Auf der Grundlage der Tagebücher (Bern/Stuttgart, 1985), pp. 522-543. 
place called Hochsteig close to the village Wattwil and the town of Lichtensteig. Although Bräker tried hard to earn his own and his family's living by spinning, weaving, or trading in cotton in the aspiring textile sector, the family was usually short of money or even in debt - in a word poor. ${ }^{6}$ Yet, not least influenced by his pietist background, Ulrich Bräker had taught himself how to read and write, and finally even became a member of the local reading society. Between 1768 and his death he almost continuously kept a diary and in the early 1780s he also wrote an autobiography (published in his lifetime under the title "Lifestory and Real Adventures of the Poor Man of Toggenburg"). ${ }^{8}$ In both writings much attention is given to health and health care. Whereas Bräker mentioned a total of 586 cases in his diaries, in which he himself, his wife, children, neighbors, friends, or kin fell ill, he reported only 16 cases, i.e. 2.7 percent, in which a professional healer (surgeon or physician) was consulted.' The following sections contain an analysis of the illnessrelated self-help strategies of Ulrich Bräker and his fellows based on Bräker's diaries and his autobiography as has been recently edited. ${ }^{10}$ As there is no in-depth study of health care in early modern rural, and in particular lower-class, households apart from McCray Beier's work on Josselin, the case of Ulrich Bräker will provide us with rare insights into this issue relevant to the renewed history of the patient. ${ }^{11}$ The

5 Cf. Alois Stadler, "Haus und Landschaft bei Ulrich Bräker", Toggenburger Annalen, 13 (1986), 71-80, p. 73 et seq.

6 Cf. Albert Tanner, "Das ganze Land eine 'Baumwollenfabrik': Ulrich Bräker als Garnhändler, Weber und kleiner Fabrikant”, Toggenburger Blätter für Heimatkunde, 36 (1985), 51-67, pp. 58-61. According to Martin Dinges the term "poor" refers to a status where someone can manage to live at subsistence level without having to call on outside or formal help. "Destitution", on the contrary, designates a status in which subsistence can no longer be achieved by means of self-help, Martin Dinges, Stadtarmut in Bordeaux 1525-1675. Alltag, Politik, Mentalitäten. Pariser Historische Studien, vol. 26 (Bonn, 1988), p. 19.

7 Cf. Alfred Messerli, "Bräkers Schreibprogramme, Schreibmotive und Schreibpraktiken in seinen Tagebüchern", in Alfred Messerli and Adolf Muschg, eds., Schreibsucht. Autobiographische Schriften des Pietisten Ulrich Bräker (1735-1798). Arbeiten zur Geschichte des Pietismus, vol. 44 (Göttingen, 2004).

8 "Lebensgeschichte und Natürliche Ebentheuer des Armen Mannes im Toggenburg".

9 Own calculation of author. Note that the initial figure does include a total of 243 references to troubles of mood and soul, most of them referring to Ulrich Bräker, thus the relative importance of formal medical treatment might actually be slightly underrated.

10 Andreas Bürgi et al., eds., Ulrich Bräker. Sämtliche Schriften, vol. I Tagebücher 17681778, rev. Alfred Messerli et al. (München, 1998); Andreas Bürgi et al., eds., Ulrich Bräker. Sämtliche Schriften, vol. II Tagebücher 1779-1788, rev. Heinz Graber et al. (München, 1998); Andreas Bürgi et al., eds., Ulrich Bräker. Sämtliche Schriften, vol. III Tagebücher 1789-1798, rev. Andreas Bürgi et al. (München, 1998); Andreas Bürgi et al., eds., Ulrich Bräker. Sämtliche Schriften, vol. IV Lebensgeschichte und vermischte Schriften, rev. Claudia Holliger-Wiesmann et al. (München, 2000). In the following Bräkers writings are quoted by date of entry/"overview"/"lifestory", (volume), page. All translations by author.

11 Cf. Christian Holliger, "Aus Ulrich Bräkers Hausapotheke", in Helmut Holzhey and Urs Boschung, eds., Gesundheit und Krankheit im 18. Jahrhundert: Referate der Tagung der 
main focus of the discussion below will include four thematic aspects: selftreatment, thematic networking, taking care of the ill, and economic support.

\section{Treating Oneself: Self-Medication and Self-Surgery}

Ulrich Bräker regularly performed self-treatment in the form of either self-medication or self-surgery when he or somebody close to him fell ill. However, rather seldom Bräker mentioned the type of drugs he relied on for self-medication. Thus, we can only learn from his diary that in 1779 he "took some medicine and let blood". ${ }^{12}$ Likewise the reader is left in the dark about the nature of the "comforting powder" which Bräker gave his neighbor, Luncie in the same year to help him get over his everyday worries. ${ }^{13}$ Anyway, there is good reason to believe that in the Toggenburg area everyday items were used as regular remedies, resulting in a rather fluid boundary between foodstuff and drugs and, obviously, moderate costs for treatment (although Bräker did not explicitly comment on the latter).

Foodstuff used to be major remedy in treating Ulrich Bräker's recurring migraine in summer 1784. As Bräker's response also provides an interesting insight regarding the relationship between self-help and outside help, a detailed chronology of events is given here. In the first week of August 1784 Bräker suffered from severe headache which he diagnosed as "the so-called migraine". ${ }^{14}$ Bräker immediately considered either taking a bath or letting blood (both were still common medical practices in Eastern Switzerland at that time), but he dismissed these plans soon as he was busy in his job at that moment. ${ }^{15}$ Two days after his first reference to migraine and still suffering from "the ever most splitting headache", Bräker walked to the town of Herisau (a distance of roughly 25 kilometers) for business reasons. ${ }^{16}$ In the evening he took a bath there which "did good". ${ }^{17}$ Nevertheless, the "furious migraine" recurred the next day and bothered him on his way back home. Thus, he let blood as soon as he had arrived in town (presumably in Lichtensteig) which brought tem-

Schweizerischen Gesellschaft zur Erforschung des 18. Jahrhunderts Bern, 1. und 2. Oktober 1993. Clio Medica, vol. 31 (Amsterdam/Atlanta, GA., 1995) for an earlier, brief overview over health care at Ulrich Bräkers'.

12 "habe etwas medicin gebraucht und adergelassen", April 27th 1779, (II), p. 77.

13 "trostbülverle", June 16th 1779, (II), p. 105.

14 "das sogenandte migrenie", August 8th 1784, (II), p. 473.

15 Ibid. Cf. Sebastian Brändli, 'Die Retter der leidenden Menschheit': Sozialgeschichte der Chirurgen und Ärzte auf der Zürcher Landschaft (1700-1850) (Zürich, 1990), pp. 83-87 with regard to surgical practice; and Urs Gantenbein, Schwitzkur und Angstschweiß: Praktische Medizin in Winterthur seit 1300. Neujahrsblatt der Stadtbibliothek Winterthur, vol. 327 (Zürich, 1996), pp. 45-53 with regard to bathing.

16 “rassentensten kopfschmertzen”, August 12th 1784, (II), p. 473.

17 "es that mir gut", ibid. 
porary relief. ${ }^{18}$ Bräker rested for two days after blood-letting and felt quite well. ${ }^{19}$ For the next roughly six weeks Bräker did not say a single word about his migraine, and it was only on Friday, October 28, that he reported on being "again seddled with a furious migraine - or however the disease was called - which [did] make [him] very ailing and weak" ${ }^{20}$ The illness forced him to stay in bed for the whole week, and so he planned to consult a doctor the next day (a market day) and follow the doctor's advice, qualifying that he would be only compliant if the physician's suggestion pleased him. ${ }^{21}$ The following afternoon Bräker walked in fact to Lichtensteig and asked Dr. Wirth for advice who recommended him to bleed. Thereafter, the suffering Bräker spent the whole Sunday at home looking forward for the surgeon to arrive at his place. ${ }^{22}$ (Unfortunately Bräker did not comment on the expenses for the professional treatment he had received). And although the bloodletting had brought again temporary relief, the pain recurred the next Monday and was even worse than before. In that situation Bräker eventually fell back on foodstuff: he applied a compress made of egg-white, flour, and spirits to his artery, and used a so-called "foot water" in addition. ${ }^{23}$ These two measures finally showed their desired effect and Bräker's pain slowly decreased. The following Sunday Bräker stated that the "worm in [his] head was still gnawing every day - but only very gently", and he never mentioned suffering from migraine again. ${ }^{24}$ As this chronology of events shows, Ulrich Bräker treated his migraine by relying on a combination of self-help and outside help, while he sought professional assistance (from a bathmaster, a surgeon, and a medical doctor) four times in the aggregate. It is interesting that self-treatment completed a sequence of unsuccessful professional therapeutic interventions; however, it seems as if no other lay person, except Bräker, did provide informal support. In addition it is worth noting that not only informal and formal aid but also different kinds of medical services drew upon each other because, against the background of the surgeons' monopoly on blood-letting, Dr. Wirth did not perform the proposed bleeding himself, but it was carried out the next day by a surgeon instead. ${ }^{25}$

18 "wüthende migreine", ibid., p. 474.

19 August 15th 1784, (II), p. 474.

20 "habe das wüthende migrenie - oder wie diese krankheit heissen mag - wieder am hals - welche mich gantz marode und kraftlos macht", October 28th 1784, (II), p. 487.

21 Ibid.

22 November 2nd 1784, (II), p. 488.

23 "fußwaßer", November 2nd 1784, (II), p. 488. According to Grimm's dictionary the term "Fuszwasser" refers either to a foot bath or, especially in Switzerland, to water in one's shoes, Deutsches Wörterbuch (rpt. München, 1984-1991), vol. 4.1.1., col. 1058.

24 "der wurm im kopf nagt noch alle tage - aber auch gar gelind", November 7th 1784, (II), p. 488.

25 Cf. Brändli, (1990), p. 57. 
Coming back to foodstuff, Ulrich Bräker appreciated both alcohol - in particular wine and spirits - and tobacco for curing head-and toothaches not least because of their analgesic effect. However, he was very particular when making a detailed entry in 1795, in that he pointed out the physical and moral dangers of spirits and that from then the only reason for him to have spirits - such "stinking water" - in his household would be their potential usefulness "as a medicine in certain cases". ${ }^{26}$ And the fact that it used to be a heavy toothache which offered adolescent Bräker the excuse to smoke in public for the first time points out the tobacco's medical reputation in the vicinity. ${ }^{27}$ In this context it is interesting to note that Bräker also occasionally applied coldness (or snow respectively) as external pain killer. ${ }^{28}$

Coffee, the consumption of which became popular in industrializing Toggenburg, was valued by Ulrich Bräker and his fellows because of its invigorating effect. ${ }^{29}$ Thus, in Mai 1783 weak Bräker was served some cups of coffee by the local pastor after he had fainted and vomited as a result of a surgeon having cupped him to cure his painful toothache. The coffee eventually restored Bräker's health though. ${ }^{30}$

In 1793 Bräker reports in his diary the story of a man who had just died although he had been served "tea or whey" by his spouse while lying in bed and suffering from nausea after excessive agricultural work. ${ }^{31}$ Bräker's reference to whey applied for the respective purpose is highly reminiscent of Simon-Andre Tissot's (17281797) widely circulated "Avis au peuple sur sa santé"; probably, this was not accidental as Ulrich Bräker had already read this paradigm work of the Enlightenment era focusing on medical education of common people in those times. Therefore Bräker's literacy must be considered as a resource for self-help, facilitating access to health-related information. It is interesting to note in this context that, apart from "Avis", he had not only read other works of Tissot, but

26 "stinkwasser", “in gewüssen fählen als artzney”, November 1795, (III), p. 594. Cf. also July 7th 1783, (II), p. 414; and September 2nd 1783, (II), p. 425.

27 Lifestory, (IV), p. 395; cf. also January 7th 1780, (II), p. 131.

28 January 7th 1780, (II), p. 131.

29 Cf. Rudolf, Braun, Industrialisierung und Volksleben: Veränderungen der Lebensformen unter Einwirkung der verlagsindustriellen Heimarbeit in einem ländlichen Industriegebiet (Zürcher Oberland) vor 1800 (Göttingen, $\left.{ }^{2} 1979\right)$, p. 95 et seq. for consumption of coffee in rural Zurich; and Edith Heischkel-Artelt, "Kaffee und Tee im Spiegel der medizinischen Literatur des 17. bis 19. Jahrhunderts", Medizinhistorisches Journal, 4 (1969), 250-260, pp. 250-254 for attitudes towards coffee in contemporary medical theory.

30 May 1st 1783, (II), p. 392; cf. also April 21st to 25th 1798, (III), p. 747.

31 "thee oder schotten", July 4th 1793, (III), p. 447.

32 Bräker directly referred to Tissot's "Avis" as early as March 30th 1787, (II), p. 549. For Tissot's advice to use whey cf. Holger Böning, "Medizinische Volksaufklärung und Öffentlichkeit. Ein Beitrag zur Popularisierung aufklärerischen Gedankengutes und zur Entstehung einer Öffentlichkeit über Gesundheitsfragen. Mit einer Bibliographie”, Internationales Archiv für Sozialgeschichte der Literatur, 15 (1990), 1-92, p. 25. 
also Cornelius Bontekoe's "Kurze Abhandlung vom menschlichen Leben" as well as Johann Georg Zimmermann's "Von der Erfahrung in der Arzneykunst", two popular books on medicine in the eighteenth century. ${ }^{33}$

It is quite clear though that Ulrich Bräker used all kinds of natural resources which the Toggenburg landscape provided for self-medication. Nevertheless he remains rather silent about any details in his writings, possibly because this knowledge seemed to be too obvious to Bräker. Yet in the 1770s Bräker entered several prayers into his journal in which he praised God particularly for having created herbs, plants, and animals not least as medicine. ${ }^{34}$ And above all, when summarizing the year 1771, he casually mentioned that "the wise herbs, like caraway lamb's lettuce nettles, were eagerly collected". ${ }^{35}$ Finally, we know from Bräker's autobiography that learning from fellows used to be one way of acquiring such kind of 'pharmaceutical' knowledge; Bräker learned about various plants from his fellows when he was a young herdsboy. ${ }^{36}$

Also animal products served as cheap means for self-help, and in particular animal fat used as an ointment. When "the poor man of Toggenburg" (so the corresponding title) went again on a journey to the general vicinity in summer 1789 and "[his] feet again happened to itch and burn dreadfully", he asked in an inn for "some tallow to rub in [his] feet" which he extensively applied to feet, socks, and shoes. ${ }^{37}$ Moreover, in the first half of the eighteenth century animal excrement was proposed as a cheap drug for self-medication in popular pharmacopoeia, for instance in Christian Franz Paulini's widely circulated "Heylsame Dreckapotheke" ${ }^{38}$ Ulrich Bräker described its application in two passages of his autobiography (written in the early 1780s), and in particular when he recalled his grandfather's death some 40 years before. Several months before he passed away the old man had dressed a wound on his thumb with "fresh warm cowpat". ${ }^{39}$ Unfortunately he used water from a well to wash away the excrement which resulted, at least in the grandson's interpretation, in a lethal dropsy. ${ }^{40}$ However, as Bräker never mentioned such treatment with animal excrement again in his diaries (reporting on the years 1768-

33 Cf. the summary in (I), p. 719.

34 Cf. October 18th 1772, (I), p. 444; August 19th 1773, (I), p. 534; and April 12th 1774, (I), p. 633.

35 "die weisen kreüter, als kümekrut rabüntzle neßlen, wurde fleisig aufgesucht", Overview 1771, (I), p. 261.

36 Lifestory, (IV), p. 387.

37 "fiengen seine füsse wieder an entsezlich zusausen und brennen", "ein bisgen unschilt seine füsse zuschmieren", July 1789, (III), p. 201. "Unschilt" or "Unschlitt" respectively used to be a kind of tallow, that is an animal fat of harder consistency, cf. "Pinguendo" in Lexikon zur Arzneimittelgeschichte (Frankfurt, 1968-1974), vol. 1, p. 58.

38 Cf. Böning, (1990), p. 6, n16.

39 "frischwarmen Kühmist", Lifestory, (IV), p. 372.

40 Ibid. Cf. also Lifestory, (IV), p. 385. 
1798), this description presumably represents first and foremost a retrospective idealization of his childhood rather than a still-practiced means of self-medication.

Apart from internal and external self-medication also minor surgeries were carried out at Bräkers' to restore the health of family members. So in Ulrich Bräker's childhood, for instance, his father once "digged up [...] with a knife" a burning and hurting wound filled with moss and grass in one of the boy's soles. ${ }^{41}$ Interesting in the context of illness and self-help is also the following episode reported by Bräker on 27 April 1780, although he did not consciously make any efforts to cure his "stinking rotting fever", his toothache, and the "ulcer in [his] mouth". ${ }^{2}$ Bräker reported that several times he had been close to stab up the ulcer with a knife - a surgery which had been carried out on him by two local medical doctors (father and son Mettler) some 30 years earlier. ${ }^{43}$ This illness episode therefore exemplifies the interaction of self-help and professional medical aid, in that therapeutic knowledge diffused literally by means of 'learning-by-experience'.

\section{Thematic Networking}

Bräker's fifth-born Jacob (1769-1787) suffered from a "consumptive disease" for most of his life which eventually caused his early death at the age of 17 in 1787.44 On 23 June 1779 Bräker entered the following episode in his journal:

I visited a sick person in Schwellbrun who is suffering from the same disease as my Jacob: visited him 5 weeks ago as well, and it is everytime the same. he tries to heal his disease constantly, not does my boy; either he is wrong or me, the outcome will show it; I am looking very much forward to seeing him again. ${ }^{45}$

At the first glance this passage does not appear to be a well chosen example for discussing medical aid in general or self-help in particular, but it rather seems to be a demonstration of medical fatalism, as Ulrich Bräker frankly admits that he had just stopped treating his ill son waiting for whatever happened. Bräker's seemingly passive attitude towards Jacob's illness is though qualified, as he had obviously consulted various healers about his son's health condition. ${ }^{46}$ But still there seems to be no reference to any measure of informal aid; however, on closer inspection this episode reveals a kind of self-help other than treatment, which will be called 'thematic

41 "grub mir's mit einem Messer heraus", Lifestory, (IV), p. 385.

42 "stinkendes faulfieber", "geschwürr im mund", April 27th 1780, (II), p. 152.

43 Lifestory, (IV), p. 475.

44 "auszehrendenkrankheit", January 11th 1787, (II), p. 524.

45 "jch besuchte einen kranken in Schwellbrun welcher die nemliche krankheit wie mein Jacob hat: habe ihn vor 5 . wochen auch besucht, und immer ists gleich. er doctert immerfort, und mein knabe nicht; entweder fählt er oder ich, der ausgang wirds weisen: bin sehr wundergirrig bis ich ihn wieder sehe.", June 23rd 1779, (II), p. 108.

46 Cf. January 11th 1787, (II), p. 523. 
networking' in the following. Apparently, Ulrich Bräker took the trouble several times in that year (from his description above we can infer at least three occasions) to walk to Schwellbrunn (located approximately 20 kilometers north-east of Bräker's place) to visit somebody whom he only refers to as a "a sick person [...] suffering from the same disease as [...] Jacob". "Therefore, Bräker's main reason for these trips was obviously a medical one, i.e. comparing the men's therapeutic progress to that of Jacob over time. As can be seen from the text, the only apparent reason for these otherwise unrelated strangers - obviously they were neither neighbors nor relatives - to socialize with each other was their respective affectedness with a specific disease. And within this lay network consumption-related experience, knowledge, and information could easily be exchanged. Seemingly, only two households were involved in 1779 . However, in early January 1788, i.e. almost exactly one year after Jacob's death, Ulrich Bräker happened to report again (unfortunately in less detail than before) that he had just visited two men who were suffering from consumption at that time. One was a "delicate youth" from Bräker's hometown Wattwil, the other lived at Moossegg (approximately 20 kilometers far away) where Bräker had stopped by on his way back home from a business trip. ${ }^{48}$ It might be presumed that thematic networking was a major issue of these visits as well.

\section{Taking Care of the Ill}

In 1788 Ulrich Bräker entered the following (assumed) soliloquy of his new neighbor, Hildebrand into his dairy, a tailor who had been "bothered" by his wife, a "nasty, roguish woman - in poor health", before she passed away: thank heavens - it's over - I have borne it - stood by my post - how would I regret it now - if I had followed some people's advice - left her - crept away - no - my heart told it to me - stand by your post - and that's what I did - and I am glad that I did it - nevertheless it seems wistful to me - that I have to shed light teardrops over her - but how would I have to tear out my hair now - if I had left her - let her dying helpless and at a loss - good people would have looked after her - but it was my duty - of course, I got frustrated with her - a great deal of effort and work $-[\ldots] .^{50}$

47 Cf. n45.

48 “zarten jüngling”, January 3rd 1788, (II), p. 631; cf. also January 6th 1788, (II), p. 633.

49 "von einem bösen, schalkhafften - kränklichen weibe geplaget”, April 13th 1788, (II), p. 701.

50 "gottlob - sist überstanden - ich habe ausgehalten - ausgeharrt - wie würds mich iez reühen - wenn ich einicher leüte rath gefolgt hete - sie verlassen - mich davon gemacht hete nein - mein hertz sagte mirs - harre aus - und das that ich - und bin froh das ichs that - s komt mir gleichwol noch so wehmüthig vor - das ich die helen tropfen um sie weynen muß - aber wie müst ich ietzt nicht die haare ausrupfen - wen ich sie verlassen hete - sie hülff u. rathlos hete 
In several ways these thoughts refer to the way health care was organized in Bräker's Toggenburg. First of all, they emphasize the fact that nursing was considered to be the duty of the immediate family, i.e. of the spouses, parents or siblings living together in one household. ${ }^{51}$ Only if this aid was either insufficient or no longer available, the broader kin was involved. The Bräker family experienced such urgent situation in fall 1771 when an epidemic of dysentery was rife in the area. Within some few days Ulrich Bräker's two oldest children - Johann Ulrich (born in 1763) and Susanna Barbara (born in 1762) - died and Ulrich Bräker himself as well as all his remaining three children fell ill, too. And although Bräker's wife Salome, who remained in good health, albeit she was seven months pregnant, took care of her suffering family members, her unmarried sister came to support her "as she couldn't serve all that". ${ }^{52}$ Sometimes formal intervention was also necessary to guarantee kinship support. Thus, Ulrich Bräker witnessed in the course of one of his trips close to Lake Constance, how the local pastor had to ask a young lunatic's "next relatives" to take care of the mentally ill girl after her sister, under whose surveillance she used to live, had passed away. ${ }^{53}$

Neighborly support constituted a further source of lay aid to cope with acute illness. That is why Ulrich Bräker did his duty when in 1787 one of his neighbors, the miller Hans Jacob Bösch (1752-1795), went "crazy in his head - speaks all kinds of insane things, from time to time coarse - obscene things" ${ }^{54}$ Bräker helped keeping Bösch under surveillance for at least two nights, assisted in chaining him up, and went several times to Böschs' because, for some reason, the mentally ill appreciated talking to him. And Bräker's comment "Bösch, gives the whole neighborhood bother" indicates above that he was not the only one to provide such neighborly support. ${ }^{55}$ Yet in Bösch's case it turned out that informal health care was insufficient and professional medical treatment became necessary instead. Therefore, the sick miller eventually (after some four weeks or so) got handed over to a physician named Dr. Forrer who took him to his nearby place where he chained him up and

sterben lassen - doch heten güte leüte - sich jhrer angenohmen - aber es war meine pflicht freylich, hate sie mir viel verdruß - viel saure müh und arbeit gemacht - [...]", ibid., p. 701 et seq.

51 Cf. January 11th 1787, (II), p. 522 for mother, and September 21st to 26th 1790, (III), p. 340 for siblings.

52 "da sie nicht allem abwarten konnte", Lifestory, (IV), p. 493. Salome originated from a village close to Wattwil, and two of her sisters were unmarried in 1771, that is Anna Katharina Ambühl (born in 1747) and Verena Ambühl (born in 1750), cf. Holliger et al., (1985), p. 66.

53 “nächsten anverwandten", September 21st to 26th 1790, (III), p. 340.

54 "verrükt im kopf - redet allerhand verirrte sachen, biswilen grobe - unflätige sachen.", October 17th 1787, (II), p. 609.

55 “Bösch, macht der gantzen nachbarschafft mühe", October 28th 1787, (II), p. 609. 
successfully treated him with humoral therapies such as purging, vomiting, and bleeding. ${ }^{56}$

Both the tailor's monologue and the behavior of the lunatic's relatives indicate how taking care of the ill (like the provision of informal aid in general) could become a burden. Therefore, potential caregivers tried to shirk their social obligation at times. This is quite well exemplified by Ulrich Bräker's behavior that day his son Jacob eventually died from consumption in 1787: while Bräker's wife Salome performed her "tender service" on the fatally ill boy (who passed away in her arms), Ulrich Bräker was absent." The father had left early that morning to Herisau seemingly to pursue his business at the local market although he admitted later half justifying and half excusing his own deed - that he had felt "the secret wish in [his] chest [...] not having to look at him passing away". ${ }^{8}$

So far we have seen how in Bräker's Toggenburg the care of physically or mentally ill and dying persons was usually organized within informal social networks involving not only the immediate family but also the broader kin and neighbors. In April 1779 though "the attendant of the ill Mrs. Liberherr" (Sara Lieberherr-Bösch, 1726-1779), who was by then suffering from a "long very painful disease", rushed into Bräker's house to call for the surgeon who happened to be present at Bräkers' ${ }^{59}$ However, in lack of any further information concerning the "attendant's" nature it is at least worth speculating that she might have provided some kind of formal health care, which she got paid for. Above all it is interesting to note in this context that Bräker did not mention whether or not his wife experienced any support from a (professional) midwife when she gave birth (three of their children were born during the time when Bräker kept his diaries). ${ }^{60}$

\section{Supporting the Ill Economically}

Ulrich Bräker called his autobiography, not without good reason, the "Lifestory and Real Adventures of the Poor Man of Toggenburg", a quite suitable characterization of his lifelong economic situation as already mentioned in the introduction. And

56 November 18th 1787, (II), p. 613. Bundt was located close to Bräker's place between the town of Lichtensteig and Wattwil. Compare in this context the similar case of Bräker's sisterin-law Anna Elisabeth who committed suicide before February 26th 1784, (II), p. 457 et seq., obviously neither Ulrich nor Salome Bräker were involved in caring for her though.

57 "zärtlicher wartung", January 11th 1787, (II), p. 522.

58 "der geheime wunsch in meiner brust entstanden seyn, sein hinscheid nicht mit anzusehen", ibid.

59 "die wärterin der kranken frau Lieberherrin", "lange sehr schmertzhaffte krankheit", April 27th 1779, (II), p. 77.

60 Cf. November 17th 1771, (I), p. 370; June 30th 1773, (I), p. 525; and Lifestory, (IV), p. 535. 
although he was never destitute, it is not difficult to imagine against such a background that financial and material questions were particularly pressing in times of illness or old age. To Bräker this topic came up for the first time in 1782 when his brother Johannes (1748-1782) died after one year of severe physical decline, loss of sight, and his resulting inability to work. In this particular case the financial burden of illness mainly rested on the shoulders of Johannes' family and, in particular, his siblings (apart from Johannes five brothers and sisters including Ulrich were still alive at that time), and Bräker thus maintained that "the help of mine a[nd] all of his poor brothers and sisters is not enough - and is wearied soon". ${ }^{61}$ Bräker's initial comment that Johannes was someone "in need of our and of other people's help" does indicate that help might have been additionally obtained from other agents outside the core family. ${ }^{6}$

The argument that Ulrich Bräker had with his own and his brother's wife regarding the acceptance of "two oertli" which the local "officer of poor relief" had offered to Johannes and which both women agreed to refuse (allegedly because taking the money would have forced them to cut expenditure on clothes), points out the fact that at least some kind of formal assistance did exist in Toggenburg to ease the worst financial hardships illness brought about. ${ }^{63}$ The amount of money distributed here, i.e. "two oertli" corresponding to a quarter of a florin or 15 kreutzer, was apparently only meant to supplement informal efforts, thus resulting in a temporal interaction of informal aid and formal assistance. ${ }^{64}$

Financial support within informal networks could easily lead to social tensions, a circumstance which is not only highlighted by Bräker's furiousness over the two women's attitude towards poor relief. Moreover, Ulrich Bräker accused his brother of insincerity and feigning his fatal illness. In his point of view Johannes only "did as if he died soon - the people believe it - and his little woman believes it, too, and

61 "die hülf, meiner u. aller seiner armen g'schwister langt nicht zu - und ist bald müde", January 23rd 1782, (II), p. 257.

62 "unser und frömder leüte hülfe nöthig hat", ibid.

63 "zwey örtli”, “armenpfleger”, ibid. In Bräker's lifetime there were no unified rules for official poor relief in the Toggenburg. However, most villages and towns somehow supported their poor by means for instance of ecclesiastical property which they had obtained in the course of Reformation, cf. Paul Wernle, Der schweizerische Protestantismus im XVIII. Jahrhundert: Erster Band. Das reformierte Staatskirchentum und sein Ausläufer (Pietismus und vernünftige Orthodoxie) (Tübingen, 1923), pp. 67-71. Although not directly related to illness compare in this context Lifestory, (IV), pp. 398-399. where Ulrich Bräker remembers the fact that in 1754 the heavily indebted family shared a house with a likewise poor woman living on alms, cf. Böning, (21998), p. 43.

64 Cf. Holliger et al., (1985), p. 476 for denominations. In October 1782 Bräker reported that a drama was staged in Lichtensteig by a traveling group which he had attended several times, and the tickets were 15 kreutzer (1st category), 8 kreutzer (2nd category), and 4 kreutzer (3rd category). Thus the amount of two oertli approximately equalled the value of two drama tickets in the best category or seven in the worst respectively, cf. October 20th 1782, (II), p. 323. 
advises him pretty well”. ${ }^{65}$ Several circumstances aroused Bräker's doubts, and shortly after Johannes' death he admitted full of remorse:

- forgive - I did you an injustice; although I hided it - but by myself - in assumption I did you an injustice - thought - because you did not complain, and always slept - so I did think, you lost nothing but face: otherwise it was mostly laziness. ${ }^{66}$

Especially Bräker's last accusation - "laziness" - emphasizes the economic dimension underlying his rage. However, it is interesting to note in this context that Bräker in fact never used the term 'illness' when referring to Johannes' health status. Instead he spoke of a "strange condition", a "curious case", or a "seldom case", thus implicitly denying the legitimacy for receiving any support. ${ }^{6}$

For Ulrich Bräker the issue of economic support became acute again only towards the end of his life cycle, but in contrast to the aforementioned case it was now him who, against the background of his just impending bankruptcy, had to rely on material and financial aid. While suffering from various physical complaints accompanied by a weakness which rendered physical work more and more impossible, he still contentedly evaluated his own situation as follows:

- what advantages I enjoy - belonging like other human beings - to the class of the poor - who quite often without service - pass away on straw and own excrement and filth without any service and the most important necessities for life - I have the best service and nursing though - I don't lack any important necessities for life my good genius always provides me with charitable people who don't let me lack anything - just now I received from a philanthropist my only one from St. G. necessary foodstuff for lots of weeks - whom God shall repay it. ${ }^{68}$

Amongst these "charitable people" were not least Bräker's neighbors who provided him with both financial and material resources: "the neighbors, too, never looked upon me more favorably - and do give me money and pleasant words they

65 "thut als wenn er bald sterben werde - die leüthe glaubens - und sein weibchen glaubts auch, und berath ihn gar gut.", March 16th 1782, (II), p. 263.

66 "verziehe - jch thate dir unrecht; zwar hab ichs verbissen - aber bey mir selbst - in vermuthungen that ich dir unrecht - dachte - wil du nichts klagtest, und immer schliefest - so dachte ich, es fähle dir nichts, als das gesicht: sonst sey es meistens faulheit.”, March 24th 1782, (II), p. 267.

67 First two quotes "selzsamen zustand" and "curioser fahl" both taken from March 16th 1782, (II), p. 263; last quote "seltener fahl” taken from March 24th 1782, (II), p. 268.

68 "- welche vorzüge genieße ich - der ich ein mensch wie andere - in die classe der armen gehöre - welche gar offt ohne wartung - im stroh und eigenem kot und unrath dahin sterben aus mangel an wartung und der nöthigsten lebens lebensbedürffnuße - ich aber habe die beste wartung und pflegung - mir fehl an keinen nöthigen lebensbedürfnußen - mein guter genius verschafft mir immer wohlthätige menschen die mir nichts mangeln lassen - eben iezo erhalte von einem menschenfründ meinem einzigen von St. G. nöthige lebensmittel auf viele wochen - dem gott vergelten wolle.", July 22nd 1798, (III), p. 788 et seq. 
wouldn't have given me otherwise - goat milk and such" ${ }^{69}$ Hence there is no reason to believe that Bräker's standing somewhere on the fringes of the village community due to his self-educatedness and his social upward mobility did have any negative consequences with regard to neighborly help. ${ }^{70}$ Above all it is interesting to note incidentally that Bräker then experienced indirect economic support from his wife's kin, too, since his impending bankruptcy was only averted as long as his spouse's relatives stood surety for his debts. ${ }^{11}$

Ulrich Bräker's most active supporters in the months prior to his death, however, were his friends from St. Gallus - not only in moral, but also in economic terms. ${ }^{72}$ These friendships were both a sign and an outcome of his social mobility, which finally resulted in a socially and geographically extended helping network. The socalled "philanthropist" from "St. G." whom Ulrich Bräker referred to in the passage quoted above used to be the wealthy bourgeois and banker Daniel Girtanner (1757-1844) living in St. Gallus with whom he had been close friends since 1791. ${ }^{73}$ Ulrich Bräker was in frequent receipt of both material ("foodstuff for lots of weeks" as cited before) and financial aid from Girtanner. And thus it happened that the last event Bräker entered into his diary was that Girtanner had just sent him "a whole box of necessities sugarsweet things". The theologian Gregor Grob (1754-1824), too, member of the same reading society like Bräker, private tutor in St. Gallus, and a mutual friend of both Girtanner and Bräker, did support the ill and elderly Bräker. Yet it was Ulrich Bräker who took the initiative in summer 1798 and wrote a letter to Grob in which he "asked [him] for putting in a good word for him in some other houses - to get some support". ${ }^{75}$ In fact, only three days later Bräker received a letter from Grob containing the reasonable amount of one luisdor (which

69 "auch die nachbarn sind gefähliger als sonst - und geben mir um gelt und gute wordte was sie mir sonst nicht gegeben häten - geißmilch u.d.g.”, July 12th 1798, (II), p. 782.

70 In his journal Bräker occasionally reported on hostility of his surrounding, for instance on April 4th 1788, (II), pp. 695-698; and March 22nd 1789, (III), 73 et seq. Cf. Holger Böning, "Gelehrte Bauern in der deutschen Aufklärung," Buchhandelsgeschichte. Aufsätze, Rezensionen und Berichte zur Geschichte des Buchwesens, 24 (1987), 1-24, pp. 17-18; and Hans-Jürgen Lüsebrink, "Die Einsamkeit des Autodidakten", in Aleida Assmann and Jan Assmann, eds., Einsamkeit. Archäologie der literarischen Kommunikation, vol. 6 (München, 2000), pp. 282 / 284.

71 Cf. April 28th 1798, (III), p. 749.

72 Cf. Hans Amann, "Ulrich Bräkers St. Galler Freund und Wohltäter", Bodensee-Hefte, 45 (1995), 22-26.

73 Cf. Samuel Voellmy, Daniel Girtanner von St. Gallen, Ulrich Bräker aus dem Toggenburg und ihr Freundeskreis: Ein Beitrag zur Geschichte der Aufklärung in der Schweiz in der 2. Hälfte des XVIII. Jahrhunderts (St. Gallen, 1928), p. 70.

74 "eine gantze schachtel voll notwendige bedürffnuße zukersüße sachen", August 14th 1798, (III), p. 797.

75 " - und ersucht in ein paar heüsern ein - gut wordt vor mich ein zulegen - um etwas unter stützung zuerhalten - ", August 12th 1798, (III), p. 797. 
equals 5 thaler or 10 florin or 40 oertli). ${ }^{76}$ In addition, a second letter reached Bräker after several days, containing "a whole pile of thaler - from my f.[riend, S.H.] Grob collected in the Gontzenbach household from the family" (whom Grob was tutoring for). ${ }^{77}$ The interaction of the two friends illustrates that, on a very practical level, not only Bräker's ability to read, but also his ability to write constituted an important resource facilitating access to informal support, and besides that receiving support in urgent situations demanded for active measures on the side of both the person in need and of those who wanted to help. Grob's fund-raising finally demonstrates how informal aid was even obtained beyond the borders of one's immediate circle, for instance from indirect acquaintances or employers of a friend respectively.

Bräker's consultations of Dr. Sulzer in the year of 1798 show how informal support in an extended social network of friends could eventually procure professional medical treatment. ${ }^{78}$ Hans Heinrich Sulzer zum Adler (1735-1814) used to be a friend of Daniel Girtanner, the city physician of Winterthur, or in Bräker's words "a skillful medical doctor - and recommended to me by my dearest Mr. G.". ${ }^{79}$ And although Bräker did not explicitly comment on whether or not he was charged for the doctor's advice, the plaster and the medication he had received, it is very likely in view of Bräker's then economic situation, that Dr. Sulzer treated him free of charge or Girtanner paid Sulzer. Therefore, this episode illustrates how the boundaries between informal self-help (here with regard to economic aspects) and professional medical aid (here in terms of treatment) occasionally blurred.

\section{Conclusion}

Starting with quantitative evidence suggesting that self-help instead of asking for professional medical assistance used to be the most common answer to illness in early modern times, the preceding discussion has scrutinized how informal health care worked in everyday life in the late eighteenth century. Through Ulrich Bräker we have gained an insight into the way how lower-class households, in particular in rural areas, handled illness-related challenges. However, dietetics as a means of both preventive and curative self-help has not been the subject here. The sections below focus on the main results regarding three central issues for our understanding of

76 Ibid.

77 "ein gantzes pak thaller - von meinem f. Grob aus dem Gontzenbachischen hauße von der familie gesamlet”, August 13th 1798, (III), p. 797.

78 Cf. April 24th 1798, (III), p. 747; Mai 29th 1798, (III), p. 761; and June 20th 1798, (III), p. 770.

79 "der ein geschikter arzt - und mir von meinem besten h. G. empfohlen ward", Mai 29th 1798, (III), p. 761. Cf. Voellmy, (1928), p. 183 for friendship of Sulzer and Girtanner, and Gantenbein, (1996), pp. 158-163 for Sulzer's biography. 
self-help strategies: Firstly, who were the agents involved in informal self-help? Secondly, which were the resources for self-help? And thirdly, who were the agents providing formal medical service, and to what extent did the interaction between informal self-help and these offers take place?

In Ulrich Bräker's surroundings, like elsewhere in early modern Europe, support for the ill was obtained within wide informal social networks centered around the person in need. ${ }^{80}$ To the extent possible, this aid was mainly organized within the core family or the household, and in this context spouses, parents and siblings were of particular significance. Such aid could also be expected from the broader kin, and in Bräker's context especially grown up siblings (as seen in the case of dysentery in 1771 as well as in the course of his brother Johannes' illness) played a significant role, however also neighbors and friends. Considering Ulrich Bräker's social upward mobility there is, hence, no reason to believe that it came out against him in terms of neighborly help, as he reported on both providing (e.g. surveillance for Bösch or medicine for Luncie) and receiving such (esp. economic aid in old age). On the contrary, his social mobility did actually add further powerful agents (first and foremost his friends Girtanner and Grob) to his own network. In addition, also acquaintances of a different character - based either on mutual friends (think of Dr. Sulzer), on an employer-employee relationship of a friend (the Gontzenbach family), on shared interest (in the case of thematic networking), or on chance (like the landlady in a random inn) - occasionally contributed to health care. Reciprocity, that is the expectation of those who provide support to receive in turn some kind of comparable service in future, obviously constituted - unspoken though for most of the time - a key principle underlying the exchange of resources in those networks Bräker encountered. ${ }^{81}$ Yet only when Ulrich Bräker accused his fatally-ill brother Johannes of dishonesty and exploiting people next to him, this seemingly self-evident truth was put in discussion.

Three groups of resources were at work in Toggenburg with regard to medical self-help and hence exchanged in those social networks: material, economic, and immaterial resources. Self-treatment at Bräkers' drew first heavily upon everyday items, in particular upon foodstuff like wine, spirits, tobacco, coffee, egg-white, and flour. All kinds of natural resources which the landscape provided such as snow, water, herbs, plants, animal fat, and - mentioned at least in two passages of his autobiography - animal excrement were applied as remedy. The costs of all of these goods were moderate. In view of the only rudimentary system of poor relief in the late eighteenth-century Toggenburg, the economic support for people suffering from a severe illness turned out to be a central challenge for the people around, and for Bräker himself this was not least an issue of life-cycle. The corresponding eco-

80 Cf. Jütte, (1994), pp. 83-86.

81 Cf. Dinges, (1998), p. 114 concerning reciprocity. 
nomic resources could come in the shape of either cash, material goods, or in indirect form (e.g. Girtanner's recommendation of Bräker to Dr. Sulzer). But financial obligations were particularly suited for triggering off social tensions (as seen in the case of Bräker's brother Johannes). Finally immaterial resources, such as knowledge on the one hand, and time, attention, and energy on the other were essential to the provision of health care, whereas the latter resources were mainly involved in taking care of the ill. In this context Bräker's thematic networking represented a suitable behavior for sharing knowledge related to a specific disease (consumption in this case). Likewise, Ulrich Bräker's literacy did not only provide him with access to the knowledge of the medical literature, but also allowed him to get into contact with potential supporters not living in the vicinity. ${ }^{82}$

Apart from self-help Ulrich Bräker mentioned several agents in his writings, providing formal assistance. Occasionally (in less than 3 percent of all cases of illness as indicated in the introduction), Bräker and his fellows sought help from medical professionals - surgeons as well as medical doctors (e.g. father and son Mettler, Dr. Wirth, Dr. Forrer, Dr. Sulzer) - to ease their physical complaints. Lucinda McCray Beier suggested in her work on Ralph Josselin that the geographical distance to the next healer, expenses, and faith in God's providence and the Divine Physician in particular could be an explanation of this marginal role of professional medical treatment. ${ }^{83}$ Compared to Ulrich Bräker's context, none of these explanations alone seems to be applicable, although economic aspects, in particular, should not be denied. However, also some kind of formal financial assistance did exist in Toggenburg to support the poor ill (as exemplified by the visit of an "officer of poor relief"). The above writings of Bräker revealed that outside aid and self-help interacted in various ways: in terms of actual medical treatment he reported on a temporary succession of both in either direction (think of Bräker's migraine or mentally ill Bösch). Yet informal and formal aid did also overlap, this could happen either in the shape of a diffusion of professional medical knowledge to everyday lay practice or by means of formal intervention initiating informal help (e.g. a pastor in case of the lunatic). And likewise, in terms of finance, those "two oertli" of poor relief offered to Bräker's brother Johannes were meant supplementary. Finally Dr. Sulzer's treatment of Ulrich Bräker on recommendation of Girtanner should remind us of the fact that the borders between outside help and self-help at times blurred.

Susanne Hoffmann is a Ph.D. student at the Institut für Geschichte der Medizin der Robert Bosch Stiftung in Stuttgart, Germany.

82 Cf. Ginnie Smith, "Prescribing the Rules of Health. Self-Help and Advice in the Late Eighteenth Century", in Roy Porter, ed., Patients and Practicioners: Lay Perceptions of Medicine in Pre-Industrial Society. Cambridge Monographs in the History of Medicine (Cambridge, 1985), p. 254 for role of popular medical literature in England.

83 McCray Beier, (1987), p. 203 et seq. 


\section{References}

\section{Primary Sources}

Bürgi, Andreas et al., eds., Ulrich Bräker. Sämtliche Schriften, vol. I Tagebücher 1768-1778, rev. Alfred Messerli et al. München, 1998.

Bürgi, Andreas et al., eds., Ulrich Bräker. Sämtliche Schriften, vol. II Tagebücher 1779-1788, rev. Heinz Graber et al. München, 1998.

Bürgi, Andreas et al., eds., Ulrich Bräker. Sämtliche Schriften, vol. III Tagebücher 1789-1798, rev. Andreas Bürgi et al. München, 1998.

Bürgi, Andreas et al., eds., Ulrich Bräker. Sämtliche Schriften, vol. IV Lebensgeschichte und vermischte Schriften, rev. Claudia Holliger-Wiesmann et al. München, 2000.

\section{Literature}

Amann, Hans, "Ulrich Bräkers St. Galler Freund und Wohltäter," Bodensee-Hefte 45 (1995), 22-26.

Böning, Holger, "Gelehrte Bauern in der deutschen Aufklärung," Buchhandelsgeschichte. Aufsätze, Rezensionen und Berichte zur Geschichte des Buchwesens 24 (1987), 1-24.

Böning, Holger, "Medizinische Volksaufklärung und Öffentlichkeit. Ein Beitrag zur Popularisierung aufklärerischen Gedankengutes und zur Entstehung einer Öffentlichkeit über Gesundheitsfragen. Mit einer Bibliographie," Internationales Archiv für Sozialgeschichte der Literatur 15 (1990), 1-92.

Böning, Holger, Ulrich Bräker. Der Arme Mann aus dem Toggenburg - Eine Biographie, überarbeitete und ergänzte Neuauflage. Zürich, ${ }^{2} 1998$.

Brändli, Sebastian, 'Die Retter der leidenden Menschheit'. Sozialgeschichte der Chirurgen und Ärzte auf der Zürcher Landschaft (1700-1850). Zürich, 1990.

Braun, Rudolf, Industrialisierung und Volksleben. Veränderungen der Lebensformen unter Einwirkung der verlagsindustriellen Heimarbeit in einem ländlichen Industriegebiet (Zürcher Oberland) vor 1800. Göttingen, ${ }^{2} 1979$.

Deutsches Wörterbuch (33 vols.). rpt. München, 1984-1991.

Dinges, Martin, Stadtarmut in Bordeaux 1525-1675. Alltag, Politik, Mentalitäten. Pariser Historische Studien, vol. 26. Bonn, 1988.

Dinges, Martin, "Self-Help and Reciprocity in Parish Assistance. Bordeaux in the Sixteenth and Seventeenth Centuries," pp. 111-125 in Peregrine Horden and Richard Smith, eds., The Locus of Care. Families, Communities, Institutions, and the Provision of Welfare since Antiquity. London, 1998. 
Gantenbein, Urs, Schwitzkur und Angstschweiß. Praktische Medizin in Winterthur seit 1300. Neujahrsblatt der Stadtbibliothek Winterthur, vol. 327. Zürich, 1996.

Heischkel-Artelt, Edith, "Kaffee und Tee im Spiegel der medizinischen Literatur des 17. bis 19. Jahrhunderts," Medizinhistorisches Journal 4 (1969), 250-260.

Holliger, Christian et al., Chronik Ulrich Bräker. Auf der Grundlage der Tagebücher. Bern/Stuttgart, 1985.

Holliger, Christian, "Aus Ulrich Bräkers Hausapotheke," pp. 25-31 in Helmut Holzhey and Urs Boschung, eds., Gesundheit und Krankheit im 18. Jahrhundert. Referate der Tagung der Schweizerischen Gesellschaft zur Erforschung des 18. Jahrhunderts Bern, 1. und 2. Oktober 1993. Clio Medica, vol. 31. Amsterdam/Atlanta, GA., 1995.

Jütte, Robert, Poverty and Deviance in Early Modern Europe. Cambridge et al., 1994. Krüger-Brand, Heike, "Vom Arzt zum Apotheker," Deutsches Ärzteblatt, Praxis 101 (2004), 4.

Lexikon zur Arzneimittelgeschichte (7 vols.). Frankfurt, 1968-1974.

Lüsebrink, Hans-Jürgen, "Die Einsamkeit des Autodidakten," pp. 281-295 in Aleida Assmann and Jan Assmann, eds., Einsamkeit. Archäologie der literarischen Kommunikation, vol. 6. München, 2000.

McCray Beier, Lucinda, Sufferers \& Healers. The Experience of Illness in SeventeenthCentury England. London/New York, 1987.

Messerli, Alfred, "Bräkers Schreibprogramme, Schreibmotive und Schreibpraktiken in seinen Tagebüchern," pp. 38-48 in Alfred Messerli and Adolf Muschg, eds., Schreibsucht. Autobiographische Schriften des Pietisten Ulrich Bräker (17351798). Arbeiten zur Geschichte des Pietismus, vol. 44. Göttingen, 2004.

Smith, Ginnie, "Prescribing the Rules of Health. Self-Help and Advice in the Late Eighteenth Century," pp. 249-282 in Roy Porter, ed., Patients and Practicioners. Lay Perceptions of Medicine in Pre-Industrial Society. Cambridge Monographs in the History of Medicine. Cambridge, 1985.

Stadler, Alois, "Haus und Landschaft bei Ulrich Bräker," Toggenburger Annalen 13 (1986), 71-80.

Tanner, Albert, "Das ganze Land eine 'Baumwollenfabrik' - Ulrich Bräker als Garnhändler, Weber und kleiner Fabrikant," Toggenburger Blätter für Heimatkunde 36 (1985), 51-67.

Voellmy, Samuel, Daniel Girtanner von St. Gallen, Ulrich Bräker aus dem Toggenburg und ihr Freundeskreis. Ein Beitrag zur Geschichte der Aufklärung in der Schweiz in der 2. Hälfte des XVIII. Jahrhunderts. St. Gallen, 1928.

Wernle, Paul, Der schweizerische Protestantismus im XVIII. Jahrhundert. Erster Band: Das reformierte Staatskirchentum und sein Ausläufer (Pietismus und vernünftige Orthodoxie). Tübingen, 1923. 